\title{
Data Keragaman Genetik Berdasarkan Karakter Morfologi pada Beberapa Aksesi Plasma Nutfah Ubi Jalar
}

\author{
Fitri Damayanti $^{*}$, Zakiah Fithah A'ini ${ }^{2}$, Giry Marhento ${ }^{2}$ \\ ${ }^{1}$ Fakultas Pascasarjana, Prodi Pendidikan MIPA,Universitas Indraprasta PGRI \\ ${ }^{2}$ Fakultas MIPA, Prodi Pendidikan Biologi, Universitas Indraprasta PGRI \\ *email: fitridamayantineng@gmail.com
}

\begin{tabular}{l} 
Article History \\
\hline Received: \\
20/09/2020 \\
Revised: \\
1/10/2020 \\
Accepted: \\
10/11/2020
\end{tabular}

Kata kunci:

Keragaman genetik Morfologi

Ubi jalar

Aksesi

Key word: Genetic diversity Morphology Sweet potato Accession

\begin{abstract}
ABSTRAK
Ubi jalar merupakan salah satu tanaman pangan penting dunia yang sangat potensial untuk dikembangkan di Indonesia. Hal ini didukung dengan keberadaan plasma nutfah yang cukup tinggi di Indonesia sehingga langkah pelestarian plasma nutfah sangat penting untuk dilakukan. Pelestarian plasma nutfah tidak saja diterapkan pada varietas yang mempunyai nilai ekonomi tinggi tetapi sangat penting diterapkan juga pada plasma nutfah yang saat ini belum diketahui nilai ekonominya. Ubi jalar yang ada belum seluruhnya terkarakterisasi sehingga kemungkinan masih banyak sumber potensi keragaman genetik ubi jalar yang belum diketahui. Oleh karena itu perlu dilakukan karakterisasi untuk mengetahui sifat genetik, morfologi, anatomi, dan agronomi tanaman untuk menghindari terjadinya duplikasi pada koleksi plasma nutfah. Sampai saat ini informasi mengenai suatu keragaman ubi jalar sangatlah terbatas, sehingga perlu dilakukan suatu tindakan agar keragaman ini dapat terpelihara dan lestari. Tujuan penelitian ini adalah untuk mengetahui karakteristik morfologi beberapa plasma nutfah ubi jalar. Penelitian ini menggunakan 12 aksesi ubi jalar yang diperoleh dari petani ubi jalar di daerah Majalengka dan ubi jalar koleksi dari BALITKABI, Malang. Dua belas aksesi ubi jalar tersebut adalah: Kidal, Salossa Papua, Antin 1, Antin 3, Beta 1, Beta 2, Sari, Sarwentar, Mentega, Manohara, Dungkul, dan Cilembu. Setiap koleksi plasma nutfah ubi jalar memiliki perbedaan morfologi yang nyata, baik pada bentuk daun, warna daun, bentuk batang, warna batang, warna kulit dan bentuk umbi serta warna umbi. Karakteristik morfologi menunjukkan keragaman genetik yang tinggi pada koleksi plasma nutfah ubi jalar.
\end{abstract}

ABSTRACT
Sweet potato is one of the important world food crops that is very potential to be developed in
Indonesia. This is supported by the existence of a high level of germplasm in Indonesia so that the
conservation of germplasm is very important. Preservation of germplasm is not only applied to
varieties that have high economic value but is very important to be applied also to germplasm
which is not yet known about its economic value. The existing sweet potato has not all been
characterized so that it is likely that there are still many sources of potential for genetic diversity
of unknown sweet potatoes. Therefore, it is necessary to characterize of the genetic plant,
morphological, anatomical and agronomic properties to avoid duplication of the germplasm
collection. Information about an accession of sweet potatoes is very limited, so an action needs to
be taken so that this diversity can be maintained and sustainable. The purpose of this study was to
determine the morphological characteristics of some sweet potato germplasm. Successfully
collected 12 sweet potato germplasm obtained from sweet potato farmers in the Majalengka area
and sweet potato collection from the BALITKABI, Malang. The twelve sweet potato accessions
were: Kidal, Papuan Salossa, Antin 1, Antin 3, Beta 1, Beta 2, Sari, Sarwentar, Mentega,
Manohara, Dungkul, and Cilembu. Each sweet potato germplasm collection had significant
morphological differences, both in leaf shape, leaf color, stem shape, stem color, skin color and
tuber shape and tuber color. Morphological characteristics showed high genetic diversity in the
sweet potato germplasm collection.

Copyright @ 2021 LPPM Universitas Indraprasta PGRI. All Right Reserved 


\section{PENDAHULUAN}

Indonesia memiliki potensi ketersediaan pangan sebagai sumber karbohidrat yang cukup besar. Hal ini ditunjang dengan keberadaan plasma nutfah ubi jalar yang cukup tinggi. Ubi jalar (Ipomoea batatas L) merupakan salah satu sumber karbohidrat dan sangat berpotensi sebagai pengganti beras dalam mendukung program diversifikasi pangan. Waluyo et al. (2013), menyatakan bahwa ubi jalar berpotensi menjadi salah satu bahan pangan. Hal ini karena kandungan nutrisi tinggi yang dimiliki ubi jalar selain itu juga mudah untuk diolah menjadi beragam aneka jenis panganan. Sejalan dengan meningkatnya kesadaran masyarakat akan pentingnya hidup sehat, maka bahan pangan yang diminati konsumen bukan saja yang mempunyai penampakan dan citarasa yang menarik, tetapi juga harus memiliki fungsi fisiologis bagi tubuh. Sehingga keberadaan senyawa antosianin pada ubi jalar ungu menjadikan jenis bahan pangan ini sangat menarik untuk diolah menjadi makanan yang mempunyai nilai fungsional.

Perubahan perilaku dan gaya hidup menyebabkan meningkatnya penyakit degeneratif seperti jantung koroner dan diabetes. Oleh karena perlu adanya perhatian akan asupan makanan guna mengurangi risiko penyakit degeneratif tersebut. Salah satunya adalah dengan mengkonsumsi sumber karbohidrat dari umbi-umbian, seperti ubi jalar. Varietas antar ubi jalar dapat dibedakan berdasarkan warna kulit dan warna umbi, yaitu berwarna putih, kuning, merah, dan ungu. Warna pada umbi ubi jalar menunjukkan kandungan nutrisi yang spesifik. Ubi jalar mengandung pigmen antosianin yang lebih tinggi terutama dari jenis ubi ungu. Kandungan senyawa antosianin ini berfungsi sebagai komponen pangan sehat. Umbi dari ubi jalar juga mengandung beta karoten, terutama yang berwarna oranye atau jingga. Betakaroten mempunyai aktivitas biologis sebagai provitamin A dan berperan sebagai antioksidan melawan radikal bebas pada tubuh (Wulandari et al., 2014).

Salah satu pusat keanekaragaman hayati di dunia atau mega diversity adalah Indonesia. Keanekaragaman hayati memegang peranan penting dalam pembangunan nasional sebagai sumberdaya hayati, sumber gen dalam program persilangan untuk menciptakan jenis unggul atau plasma nutfah baru atau sebagai sistem penyangga kehidupan pangan. Sebagai konsekuensi pembangunan, keberadaan plasma nutfah terancam punah. Hal ini terjadi akibat dari perubahan fungsi habitat dan eksploitasi yang berlebihan namun tanpa diikuti dengan pengelolaan yang memadai sehingga populasinya terus menurun dan pada akhirnya akan terjadi kepunahan. Oleh karena itu plasma nutfah perlu dilestarikan dan dikembangkan bersama untuk mempertahankan keanekaragaman hayati. Tindakan pelestarian plasma nutfah tidak saja diterapkan pada plasma nutfah yang mempunyai nilai ekonomi tinggi (komersial) tetapi sangat penting diterapkan juga pada plasma nutfah yang saat ini belum diketahui nilai ekonominya. Hal ini karena belum diketahuinya sifat-sifat unggul yang dikandungnya sehingga nyaris tidak dibudidayakan oleh petani. Selain itu perlu juga dilakukan karakterisasi untuk mengetahui sifat genetik, morfologi, anatomi, dan agronomi tanaman.

Salah satu karakter dalam evaluasi keragaman genetik plasma nutfah ubi jalar yang dapat dilakukan adalah karakter morfologi. Karakterisasi morfologi dapat digunakan untuk melihat hubungan kekerabatan seperti pada talas (Damayanti, 2009), pisang (Damayanti \& Roostika, 2010), salak (Fatimah, 2013), mangga (Fitmawati et al., 2013), dan ubi jalar (Warhamni et al., 2013; Laurie et al., 2013; Utari et al., 2017; Musyarifah et al., 2018). Informasi keragaman genetik berdasarkan karakteristik morfologi sangat penting dilakukan untuk menghindari terjadinya duplikasi pada koleksi plasma nutfah. Ubi jalar yang ada belum sepenuhnya terkarakterisasi sehingga banyak sumber potensi keragaman genetik ubi jalar yang belum diketahui. Karakterisasi morfologi penting dilakukan untuk melihat hubungan kekerabatan pada beberapa plasma nutfah ubi jalar. Selain itu juga perlu dilakukan analisis keragaman genetik dan hubungan kekerabatan di antara plasma nutfah ubi jalar untuk program pemuliaan tanaman dan manajemen konservasi plasma nutfah ubi jalar, hal ini sejalan dengan Glato et al. (2017). Maquia et al. (2013) melaporkan bahwa analisis karakterisasi morfologi yang dipadukan dengan karakteristik molekuler dan agronomi dapat memberikan nilai penting terhadap ekonomi dan ketahanan pangan, seperti mendapatkan karakter yang sesuai dengan daerah rawan kekeringan.

Penelitian ini bertujuan untuk mempelajari karakteristik morfologi untuk melihat tingkat keragaman genetik pada beberapa koleksi plasma nutfah ubi jalar. Aplikasi dari penelitian ini diharapkan dapat memberikan informasi mengenai karakter morfologi pada beberapa aksesi ubi jalar. Selain itu diharapkan dapat membantu program 
pemerintah dalam usaha pelestarian plasma nutah ubi jalar dan pengembangannya.

\section{METODE PENELITIAN}

Bahan tanaman yang digunakan dalam penelitian ini adalah beberapa koleksi plasma nutfah ubi jalar yang diperoleh dari petani ubi jalar daerah Majalengka dan koleksi ubi jalar dari Balai Penelitian Aneka Kacang dan Umbi (BALITKABI), Malang dan Majalengka. Tahapan kegiatan dalam penelitian ini adalah: 1) koleksi plasma nutfah ubi jalar, 2) pengamatan keragaman berdasarkan ciri morfologi, dan 3) uji organoleptik.

\section{Koleksi plasma nutfah ubi jalar}

Plasma nutfah ubi jalar yang dikoleksi diperoleh dari petani ubi jalar daerah Majalengka dan koleksi BALITKABI, Malang. Koleksi plasma nutfah ubi jalar yang ada kemudian diidentifikasi dan diklasifikasi.

2. Pengamatan keragaman berdasarkan ciri morfologi

Data morfologi ubi jalar dilakukan berdasarkan deskriptor ubi jalar, yaitu data kualitatif yang meliputi: bentuk daun, tipe lekukan daun, ujung daun, pangkal daun, tepi daun, daging daun, warna daun muda, warna daun tua, permukaan daun, bentuk batang, jenis batang, permukaan batang, arah tumbuh batang, arah tumbuh cabang, penutupan tanah, ruas batang, ruas tangkai, diameter tangkai, diameter batang, warna batang, warna tangkai, bentuk umbi, warna kulit umbi, dan warna umbi.

3. Uji organoleptik

Uji organoleptik dilakukan untuk mengetahui aksesi ubi jalar yang lebih disukai. Penilaian terhadap uji organoleptik meliputi tekstur, warna, rasa, dan aroma umbi.

\section{HASIL DAN PEMBAHASAN}

\section{Karakteristik Morfologi Beberapa Koleksi Plasma Nutfah Ubi Jalar}

Koleksi plasma nutfah ubi jalar yang diperoleh dari petani ubi jalar daerah Majalengka dan koleksi ubi jalar dari Balai Penelitian Aneka Kacang dan Umbi (BALITKABI), Malang dan Majalengka. Terdapat 12 aksesi ubi jalar yang berhasil dikoleksi, yaitu Kidal, Papua Salossa, Antin 1, Antin 3, Beta 1, Beta 2, Sari, Sarwentar, Mentega, Manohara, Dungkul, dan Cilembu. Secara umum setiap koleksi plasma nutfah ubi jalar memiliki perbedaan morfologi secara nyata, terlihat dari bentuk daun, warna daun, bentuk batang, ataupun warna batang (Tabel 1).

Morfologi daun dari beberapa koleksi plasma nutfah ubi jalar dapat dilihat pada Gambar 1. Karakter morfologi daun dari koleksi plasma nutfah ubi jalar yang ada memperlihatkan adanya keragaman genetik antar aksesi ubi jalar. Hal ini dapat digunakan sebagai pembeda antar aksesi. Aksesi-aksesi ubi jalar yang ada kemungkinan terbentuk dari hasil persilangan secara alami di alam dan melalui persilangan buatan. Hasil penelitian Hetharie et al. (2017) memperlihatkan bahwa karakterisasi in situ pada warna dan bentuk dari daun dan batang ubi jalar dapat digunakan sebagai pembeda aksesi ubi jalar. Karakteristik morfologi daun seperti bentuk, pola lekuk, dan jumlah lekuk adalah karakter yang bersifat kualitatif dan tidak dipengaruhi oleh lingkungan.

Tabel 1. Data morfologi beberapa koleksi plasma nutfah ubi jalar

\begin{tabular}{|c|c|c|c|}
\hline No. & Aksesi & & Ciri Morfologi \\
\hline \multirow{3}{*}{1.} & \multirow{3}{*}{ Kidal } & Daun & $\begin{array}{l}\text { Daun berbentuk jantung, tidak bertoreh. Ujung daun runcing dengan pangkal daun } \\
\text { meruncing. Tepi daun rata, daging daun tipis seperti selaput. Warna daun muda } \\
\text { hijau muda dan menjadi hijau keunguan bila sudah dewasa. Permukaan daun licin } \\
\text { suram. }\end{array}$ \\
\hline & & Batang & $\begin{array}{l}\text { Batang berbentuk bulat dengan jenis yang basah. Permukaan batang licin dengan } \\
\text { arah tumbuh yang menyebar. Ruas batang panjang dengan tangkai batang yang } \\
\text { pendek. Percabangan tumbuh menyebar. Diameter batang sangat tipis. Warna } \\
\text { batang hijau gelap dengan tangkai berwarna ungu. Pertumbuhan ubi jenis ini tinggi } \\
\text { menutupi tanah. }\end{array}$ \\
\hline & & Umbi & $\begin{array}{l}\text { Umbi berbentuk memanjang dengan warna kulit umbi ungu kemerahan. Umbi } \\
\text { berwarna ungu. }\end{array}$ \\
\hline \multirow{2}{*}{2.} & \multirow{2}{*}{$\begin{array}{l}\text { Papua } \\
\text { Salossa }\end{array}$} & Daun & $\begin{array}{l}\text { Daun berbentuk tombak, berbagi. Ujung daun runcing dengan pangkal daun } \\
\text { berlekuk. Tepi daun rata, daging daun tipis lunak. Daun muda berwarna hijau } \\
\text { kemerahan dan menjadi hijau gelap bila sudah dewasa. Permukaan daun gundul. }\end{array}$ \\
\hline & & Batang & $\begin{array}{l}\text { Batang berbentuk persegi dengan jenis yang keras. Permukaan batang licin dengan } \\
\text { arah tumbuh yang tegak lurus. Ruas batang sedang dengan tangkai batang yang } \\
\text { sangat panjang. Percabangan tumbuh menyebar. Diameter batang tebal. Warna }\end{array}$ \\
\hline
\end{tabular}


batang hijau ungu gelap dengan tangkai berwarna hijau. Pertumbuhan ubi jenis ini menyeluruh menutupi tanah.

\begin{tabular}{|c|c|c|c|}
\hline & & Umbi & $\begin{array}{l}\text { Umbi berbentuk memanjang dengan warna kulit umbi kuning demikian juga } \\
\text { dengan warna umbinya. }\end{array}$ \\
\hline \multirow{3}{*}{3.} & \multirow{3}{*}{ Antin 1} & Daun & $\begin{array}{l}\text { Daun berbentuk tombak, berbagi. Ujung daun runcing dengan pangkal daun } \\
\text { berlekuk. Tepi daun rata, daging daun tipis lunak. Daun muda berwarna hijau } \\
\text { kekuningan dan menjadi hijau ungu gelap bila sudah dewasa. Permukaan daun } \\
\text { gundul. }\end{array}$ \\
\hline & & Batang & $\begin{array}{l}\text { Batang berbentuk persegi dengan jenis yang keras. Permukaan batang licin dengan } \\
\text { arah tumbuh semi tegak. Ruas batang pendek dengan tangkai batang sedang. } \\
\text { Percabangan tumbuh tegak lurus. Diameter batang sedang. Warna batang hijau } \\
\text { keunguan dengan tangkai berwarna ungu. Pertumbuhan ubi jenis ini sedang } \\
\text { menutupi tanah. }\end{array}$ \\
\hline & & Umbi & $\begin{array}{l}\text { Umbi berbentuk memanjang dengan warna kulit umbi putih dan warna umbi ungu } \\
\text { kekuningan. }\end{array}$ \\
\hline \multirow{3}{*}{4.} & \multirow{3}{*}{ Antin 3} & Daun & $\begin{array}{l}\text { Daun berbentuk bulat telur. Ujung daun runcing dengan pangkal daun rata. Tepi } \\
\text { daun rata, daging daun tipis lunak. Daun muda berwarna hijau kekuningan dan } \\
\text { menjadi hijau ungu gelap bila sudah dewasa. Permukaan daun gundul. }\end{array}$ \\
\hline & & Batang & $\begin{array}{l}\text { Batang berbentuk persegi dengan jenis yang keras. Permukaan batang licin dengan } \\
\text { arah tumbuh semi tegak. Ruas batang pendek dengan tangkai batang sedang. } \\
\text { Percabangan tumbuh tegak lurus. Diameter batang sedang. Warna batang hijau } \\
\text { keunguan dengan tangkai berwarna ungu. Pertumbuhan ubi jenis ini sedang } \\
\text { menutupi tanah. }\end{array}$ \\
\hline & & Umbi & $\begin{array}{l}\text { Umbi berbentuk memanjang dengan warna kulit umbi putih dan warna umbi ungu } \\
\text { kekuningan. }\end{array}$ \\
\hline
\end{tabular}

Aksesi ini memiliki daun berbentuk jantung, tidak bertoreh. Ujung daun runcing

Daun dengan pangkal daun berlekuk. Tepi daun rata, daging daun tipis lunak. Daun tua berwarna hijau ungu gelap.

Batang berbentuk persegi dengan jenis yang keras. Permukaan batang licin dengan

5. Beta 1 arah tumbuh yang menyebar. Ruas batang pendek dengan tangkai batang pendek.

Batang Percabangan tumbuh tegak lurus. Diameter batang sedang. Warna batang hijau cerah dengan tangkai berwarna ungu. Pertumbuhan ubi jenis ini sedang menutupi tanah.

Umbi Umbi berbentuk memanjang dengan warna kulit umbi ungu kemerahan dan umbi berwarna jingga.

Daun berbentuk tombak, berlekuk. Ujung daun runcing dengan pangkal daun

Daun berlekuk. Tepi daun rata, daging daun tipis lunak. Daun muda berwarna hijau kekuningan dan menjadi hijau ungu gelap bila sudah dewasa. Permukaan daun gundul.

Batang berbentuk bulat dengan jenis yang keras. Permukaan batang licin dengan

6. Beta 2 arah tumbuh yang tegak lurus. Ruas batang pendek dengan tangkai batang sedang.

Batang Percabangan tumbuh tegak lurus. Batang berdiameter sedang. Warna batang hijau cerah dengan tangkai berwarna hijau. Pertumbuhan ubi jenis ini tinggi menutupi tanah.

Umbi Umbi berbentuk memanjang dengan warna kulit umbi merah dan warna umbi kuning.

Daun berbentuk tombak, berlekuk. Ujung daun runcing dengan pangkal daun

Daun berlekuk. Tepi daun rata, daging daun tipis lunak. Daun muda berwarna hijau kemerahan dan menjadi hijau keunguan bila sudah dewasa. Permukaan daun gundul.

7. Sari

Batang berbentuk persegi dengan jenis yang keras. Permukaan batang licin dengan arah tumbuh yang semi tegak. Ruas batang sedang dengan tangkai batang sedang.

Batang Percabangan tumbuh tegak lurus. Batang berdiameter sedang. Warna batang hijau cerah dengan tangkai berwarna hijau. Pertumbuhan ubi jenis ini tinggi menutupi tanah.

Umbi Umbi berbentuk bulat panjang dengan warna kulit umbi merah. Warna umbi kuning. 


\begin{tabular}{|c|c|c|c|}
\hline \multirow{3}{*}{8.} & \multirow{3}{*}{ Sarwenta } & Daun & $\begin{array}{l}\text { Daun berbentuk jantung, tidak bertoreh. Ujung daun runcing dengan pangkal daun } \\
\text { rata. Tepi daun rata, daging daun tipis lunak. Daun berwarna hijau suram. } \\
\text { Permukaan daun gundul. }\end{array}$ \\
\hline & & Batang & $\begin{array}{l}\text { Batang berbentuk persegi dengan jenis yang keras. Permukaan batang kasap } \\
\text { dengan arah tumbuh yang tegak lurus. Ruas batang pendek dengan tangkai batang } \\
\text { pendek. Percabangan tumbuh tegak lurus. Batang berdiameter sedang. Warna } \\
\text { batang hijau keunguan dengan tangkai berwarna hijau dibagian pangkalnya. } \\
\text { Pertumbuhan ubi jenis ini tinggi menutupi tanah. }\end{array}$ \\
\hline & & Umbi & $\begin{array}{l}\text { Umbi berbentuk memanjang dengan warna kulit umbi merah. Umbi berwarna } \\
\text { kuning. }\end{array}$ \\
\hline \multirow{3}{*}{9.} & \multirow{3}{*}{ Mentega } & Daun & $\begin{array}{l}\text { Daun berbentuk segitiga, tidak bertoreh. Ujung daun runcing dengan pangkal daun } \\
\text { berlekuk. Tepi daun rata, daging daun tipis lunak. Daun muda berwarna hijau muda } \\
\text { dan menjadi hijau suram pada daun dewasa. Permukaan daun gundul. }\end{array}$ \\
\hline & & Batang & $\begin{array}{l}\text { Batang berbentuk bulat dengan jenis yang keras. Permukaan batang licin dengan } \\
\text { arah tumbuh yang tegak lurus. Ruas batang sedang dengan tangkai batang sangat } \\
\text { panjang. Percabangan tumbuh tegak lurus. Batang berdiameter sedang. Warna } \\
\text { batang hijau cerah dengan tangkai berwarna hijau pada bagian pangkal. } \\
\text { Pertumbuhan ubi jenis ini sedang menutupi tanah. }\end{array}$ \\
\hline & & Umbi & $\begin{array}{l}\text { Umbi berbentuk memanjang dengan warna kulit umbi merah. Umbi berwarna } \\
\text { kuning. }\end{array}$ \\
\hline \multirow{3}{*}{10.} & \multirow{3}{*}{ Manohara } & Daun & $\begin{array}{l}\text { Daun berbentuk bulat, berbagi dalam. Ujung daun meruncing dengan pangkal daun } \\
\text { rata. Tepi daun rata, daging daun tipis lunak. Daun muda berwarna hijau kemerahan } \\
\text { dan menjadi hijau keunguan pada daun dewasa. Permukaan daun licin (mengkilap). }\end{array}$ \\
\hline & & Batang & $\begin{array}{l}\text { Batang berbentuk bulat dengan jenis yang keras. Permukaan batang licin dengan } \\
\text { arah tumbuh yang tegak lurus. Ruas batang pendek dengan tangkai batang sangat } \\
\text { panjang. Percabangan tumbuh tegak lurus. Batang berdiameter sedang. Warna } \\
\text { batang hijau ungu gelap dengan tangkai berwarna ungu. Pertumbuhan ubi jenis ini } \\
\text { sedang menutupi tanah. }\end{array}$ \\
\hline & & Umbi & Umbi berbentuk bulat telur dengan warna kulit umbi putih. Umbi berwarna putih. \\
\hline \multirow{3}{*}{11.} & \multirow{3}{*}{ Dungkul } & Daun & $\begin{array}{l}\text { Daun berbentuk jantung, berlekuk. Ujung daun meruncing dengan pangkal } \\
\text { berlekuk. Tepi daun rata, daging daun tipis lunak. Daun muda berwarna hijau muda } \\
\text { dan hijau kgelap pada daun dewasa. Permukaan daun licin (mengkilap). }\end{array}$ \\
\hline & & Batang & $\begin{array}{l}\text { Batang berbentuk bulat dengan jenis yang keras. Permukaan batang licin dengan } \\
\text { arah tumbuh yang tegak lurus. Ruas batang sedang dengan tangkai batang panjang. } \\
\text { Percabangan tumbuh menyebar. Batang berdiameter sedang. Warna batang hijau } \\
\text { cerah dengan tangkai berwarna hijau. Pertumbuhan ubi jenis ini sedang menutupi } \\
\text { tanah. }\end{array}$ \\
\hline & & Umbi & $\begin{array}{l}\text { Umbi berbentuk memanjang dengan warna kulit umbi jingga. Umbi berwarna } \\
\text { kuning. }\end{array}$ \\
\hline \multirow{3}{*}{12.} & \multirow{3}{*}{ Cilembu } & Daun & $\begin{array}{l}\text { Daun berbentuk jantung, berlekuk. Ujung daun runcing dengan pangkal berlekuk. } \\
\text { Tepi daun rata, daging daun tipis lunak. Daun muda berwarna hijau kemerahan dan } \\
\text { hijau keunguan pada daun dewasa. Permukaan daun licin (mengkilap). }\end{array}$ \\
\hline & & Batang & $\begin{array}{l}\text { Batang berbentuk bulat dengan jenis yang keras. Permukaan batang licin dengan } \\
\text { arah tumbuh yang tegak lurus. Ruas batang sedang dengan tangkai batang sedang. } \\
\text { Percabangan tumbuh menyebar. Batang berdiameter sedang. Warna batang hijau } \\
\text { suram dengan tangkai berwarna hijau. Pertumbuhan ubi jenis ini sedang menutupi } \\
\text { tanah. }\end{array}$ \\
\hline & & Umbi & $\begin{array}{l}\text { Umbi berbentuk bulat panjang dengan warna kulit ungu kemerahan. Umbi } \\
\text { berwarna kuning. }\end{array}$ \\
\hline
\end{tabular}




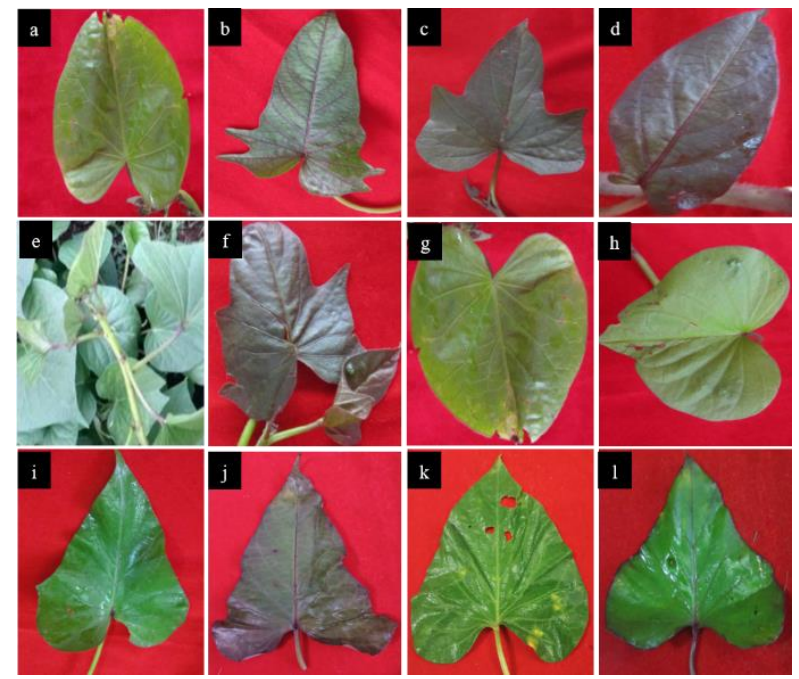

Gambar 1. Morfologi daun beberapa koleksi plasma nutfah ubi jalar. a. Kidal; b. Papua Salossa; c. Antin 1; d. Antin 3; e. Beta 1; f. Beta 2; g. Sari; h. Sarwentar; i. Mentega; j. Manohara; k. Dungkul; 1. Cilembu

Karakter umbi dari koleksi plasma nutfah ubi jalar memperlihatkan keragaman genetik yang tinggi antar aksesi (Gambar 2). Bentuk umbi memperlihatkan keragaman yang tinggi demikian juga dengan warna kulit umbi sangat bervariasi antar aksesi. Hal ini menunjukkan tingginya keragaman genetik pada plasma nutfah ubi jalar yang berhasil dikoleksi.

Keragaman warna umbi memperlihatkan tingginya variasi genetik antar aksesi pada koleksi plasma nutfah ubi jalar (Gambar 3). Keragaman pada warna umbi terlihat mulai dari warna umbi yang putih kekuningan sampai ungu gelap. Tingkat keragaman genetik pada warna umbi dapat digunakan sebagai informasi untuk kandungan antosianin. Beberapa peneliti menyatakan bahwa tingginya kandungan antosianin berhubungan warna umbi. Hasil penelitian Minantyorini \& Andarini (2016) memperlihatkan sembilan variasi warna pada kulit umbi jalar, yaitu mulai dari warna putih sampai ungu gelap. Pembentukan warna pada kulit dan umbi ubi jalar karena adanya pigmen karotenoid oranye dan antosianin ungu. Komposisi dan berbandingan yang berbeda antara pigmen karotenoid oranye dan antosianin ungu akan menghasilkan warna yang beragam pada kulit dan daging ubi jalar.

Keragaman genetik dari karakter morfologi dapat digunakan untuk mengetahui hubungan kekerabatan antar aksesi pada koleksi plasma nutfah. Namun hal ini belum berhasil dilakukan karena terkendala pada beberapa karakter yang belum dapat diamati. Data hubungan kekerabatan sangat berguna bagi para pemulia tanaman.

\section{Uji Organoleptik pada Beberapa Plasma Nutfah Ubi Jalar}

Hasil uji organoleptik menunjukkan bahwa Cilembu adalah aksesi yang paling banyak disukai dari 12 koleksi plasma nutfah ubi jalar yang ada (Tabel 2). Hal ini berhubungan dengan tekstur umbi Cilembu yang lembut dan manis. Sedangkan yang paling tidak disukai adalah Kidal. Hal ini sebabkan karena tekstur kidal yang keras dan kasar. Warna yang paling disukai adalah Beta 2 dan yang paling tidak disukai adalah Papua Salossa. Warna dari Beta 2 adalah ungu cerah. Aroma yang paling disukai adalah Cilembu dan yang tidak disukai adalah Antin 3.

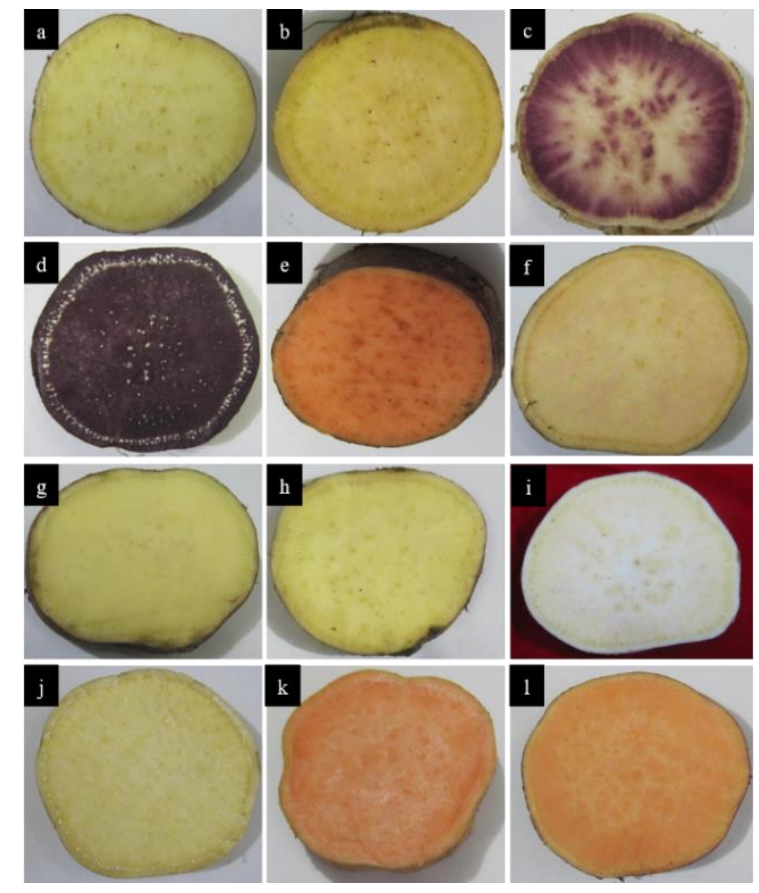

Gambar 3. Morfologi warna umbi dari beberapa koleksi plasma nutfah ubi jalar. a. Kidal; b. Papua Salossa; c. Antin 1; d. Antin 3; e. Beta 1; f. Beta 2; g. Sari; h. Sarwentar; i. Mentega; j. Manohara; k. Dungkul; 1. Cilembu

Umumnya semua panelis pada penelitian ini menyukai rasa umbi yang manis seperti umbi Cilembu dan Sarwentar yang memiliki warna umbi cenderung kuning sampai kuning muda. Hal ini berkaitan dengan kandungan gula pada umbi. Hasil penelitian Minantyorini \& Andarini (2016) pada beberapa plasma nutfah ubi jalar memperlihatkan umbi yang memiliki kadar gula tinggi diperoleh dari aksesi yang mempunyai warna daging umbi kuning sampai kuning muda. Selain itu hasil penelitian De Oliveira et al. (2015) menunjukkan bahwa daging umbi pada ubi jalar yang berwarna kekuningan memiliki kandungan 
karbohidrat, pati, dan nilai energi total yang lebih tinggi dibandingkan daging umbi berwarna putih. Umbi berwarna kekuningan mengandung vitamin A yang lebih tinggi.
Hasil penelitian ini memperlihatkan bahwa jenis ubi jalar yang lebih disukai sebagai panganan adalah yang memiliki rasa manis, warna yang menarik, dan bertekstur remah.

Tabel 2. Uji organoleptik beberapa plasma nutfah ubi jalar

\begin{tabular}{|c|c|c|c|c|c|c|c|c|c|c|c|c|}
\hline \multirow{2}{*}{ Jenis Uji } & \multicolumn{12}{|c|}{ Aksesi Ubi Jalar } \\
\hline & $\mathbf{A}$ & B & $\mathbf{C}$ & D & $\mathbf{E}$ & $\mathbf{F}$ & $\mathbf{G}$ & $\mathbf{H}$ & I & $\mathbf{J}$ & $\mathbf{K}$ & $\mathbf{L}$ \\
\hline Tekstur & 2,55 & 3,61 & 3,34 & 2,86 & 3,52 & 3,45 & 3,59 & 3,73 & 3,87 & 2,96 & 2,65 & 3,98 \\
\hline Warna & 3,41 & 3,16 & 3,20 & 3,59 & 3,34 & 3,75 & 3,43 & 3,55 & 2,98 & 2,87 & 3,35 & 3,86 \\
\hline Aroma & 2,75 & 3,32 & 2,95 & 2,91 & 3,43 & 3,32 & 3,36 & 3,48 & 3,56 & 2,67 & 2,80 & 3,98 \\
\hline Rasa & 2,66 & 3,68 & 3,14 & 2,91 & 3,57 & 3,43 & 3,64 & 3,88 & 3,78 & 2,56 & 2,57 & 3,98 \\
\hline
\end{tabular}

Keterangan: A=Kidal; B. Papua Salossa; C. Antin 1; D. Antin 3; E. Beta 1; F. Beta 2; G. Sari; H. Sarwentar; I.

Mentega; J. Manohara; K. Dungkul; L. Cilembu.

\section{KESIMPULAN}

Setiap koleksi plasma nutfah ubi jalar memiliki perbedaan morfologi secara nyata, baik dari bentuk daun, warna daun, bentuk batang, warna batang, warna kulit dan bentuk umbi serta warna umbinya. Karakteristik morfologi memperlihatkan keragaman genetik yang tinggi pada koleksi plasma nutfah ubi jalar. Jenis ubi jalar yang lebih disukai adalah Cilembu dan Sarwentar, dimana kedua aksesi ini memiliki rasa manis, warna yang menarik, dan bertekstur remah. Perlu dilakukan pengamatan karakter sitologi dan anatomi untuk melihat keragaman genetik pada koleksi plasma nutfah ubi jalar. Selain itu perlu dilakukan uji lanjut untuk mengetahui hubungan kekerabatan antar aksesi ubi jalar.

\section{DAFTAR PUSTAKA}

Damayanti, F. (2009). Karakterisasi morfologi dan analisis jumlah kromosom beberapa plasma nutfah talas asal kabupaten Kutai Barat Kalimantan Timur. Majalah Ilmiah Faktor, Juli-Agustus, 11-19.

Damayanti, F., \& Roostika, I. (2010). Koleksi plasma nutfah pisang secara ex-vitro dan in vitro serta kajian sitologi dan analisa keragaman antar karakter berdasarkan penanda fenotipe. Faktor Exacta, 3(2), 145-157.

Fatimah, S. (2013). Analisis morfologi dan hubungan kekerabatan sebelas jenis tanaman salak (Salacca zalacca (gertner) voss Bangkalan. Agrovigor, 6(1), 1-15.

Fitmawati., Swita, A., Sofyanti, N., \& Herman. (2013). Analisis kekerabatan morfologi. Floribunda, 4(7), 169-174.

De Oliveira, K., Lopes, D. S., Takeiti, C. Y., Barbosa, J. L., \& Barbosa, M. I. M. J. (2015).
Physicochemical characteristics of tubers from organic sweet potato roots. Revista Caatinga, 28(2), 225-234.

Glato, K., Aidam, A., Kane, N. A., Bassirou, D., Couderc, M., Zekraoui, L., Scarcelli, N., Barnaud, A., \& Vigouroux, Y. (2017). Structure of sweet potato (Ipomoea batatas) diversity in West Africa covaries with a climatic gradient. PLoS ONE, 12(5), 1-17. https://doi.org/10.1371/journal.pone.0177697.

Hetharie, H., Raharjo, S. H. T., Augustyn, G. H., \& Pesireron, M. (2017). Akurasi karakterisasi tingkat in situ tanaman ubi jalar pada dua kecamatan di Kabupaten Seram bagian barat. $J$. Budidaya Pertanian, 13(2), 103-110.

Laurie, S. M., Calitz, F. J., Adebola, P. O., \& Lezar, A. (2013). Characterization and evaluation of South African sweet potato (Ipomoea batatas (L.) LAM) land races. South African Journal of Botany, 85, 10-16.

Maquia, I., Muocha, I., Naico, A., Martins, N., Gouveia, M., Andrade, I., Goulao, L. F., \& Ribeiro, A. I. (2013). Molecular, morphological and agronomic characterization of the sweet potato (Ipomoea batatas L.) germplasm collection from Mozambique: Genotype selection for drought prone regions. South African Journal of Botany, 88, 142-151. https://doi.org/10.1016/j.sajb.2013.07.008

Minantyorini., \& Andarini, Y. N. (2016). Keterkaitan karakteristik morfologi tanaman ubi jalar dengan kadar gula dan kadar bahan kering umbi. Prosiding Seminar Hasil Penelitian Tanaman Aneka Kacang dan Umbi: 588-596.

Musyarifah, M., Rosmayati., \& Damanik, R. I. M. (2018). Identifikasi karakter morfologis dan hubungan kekerabatan tanaman ubi jalar (Ipomoea batatas L.) di Kabupaten Simalungun 
dan Kabupaten Dairi. Agroekoteknologi, 6(4), 826- 835.

Utari, D. S., Kardhinata, E. H., \& Damanik, R. I. M. (2017). Karakter morfologis dan hubungan kekerabatan tanaman ubu jalar (Ipomoea Batatas 1.) di dataran tinggi dan dataran rendah Sumatera Utara. Agroekoteknologi, 5(4), 870881.

Wulandari, B., Ishartani, D., \& Afandi, D. R. (2014). Penggunaan pemanis rendah kalori pada pembuatan velva ubi jalar oranye (Ipomoea batatas L.). Jurnal Teknosains Pangan, 3(3), 12-21.
Waluyo, B., Istifadah, N., Ruswandi, D., \& Kurniawan, A. (2013). Karakteristik umbi dan kandungan kimia ubi jalar untuk mendukung penyediaan bahan pangan dan bahan baku industri. Prosiding Semnas 3 in One: 373-375

Warhamni., Boer, D., \& Muzuni. (2013). Keragaman morfologi ubi jalar (Ipomoea batatas (L.) Lam.) asal Kabupaten Muna. Agroteknos, 3(2), 121-126. 